Reprod. Nutr. Dévelop., 1980, 20 (3 B), 807-816.

\title{
Mutual recognition between ewes and lambs
}

\author{
par Elizabeth SHILLITO WALSER, G. ALEXANDER * \\ ARC Institufe of Animal Physiology, Babraham, \\ Cambridge CB2 4AT, England \\ * C.S.I.R.O. Division of Animal Production, \\ Prospect, N.S.W., Australia
}

Summary. Studies to investigate the relative value of sight, hearing and smell in mutual recognition between ewes and lambs are described. The method used was to alter clues that could aid in recognition, rather than interfering with the animal's sensory perception. When lambs were coloured with powdered dyes to change appearance, this produced marked avoidance by the dams of the treated lambs. When lambs were partially coloured, the ewes' greatest reaction was shown to lambs whose heads were coloured. Other experiments compared the role of vision and hearing by observing recognition when the ewes or lambs were hidden behind screening, or muted. The results indicate that while olfaction is important for recognition when the ewe and lamb are close together, visual clues are of major importance in maternal discrimination and auditory clues are important for the lambs as they get older.

During the last five years, the nature of the ewe-lamb bond and the way in which ewes and lambs recognise each other has been studied by several workers. This paper reviews the contribution made by us, working in Australia on Merino sheep and in England on several breeds of sheep mostly Clun Forest, Jacob and Dalesbred.

\section{Maternal behaviour in sheep.}

Sheep live in matriarchal flocks, both under husbandry conditions and when feral. The lambs are « followers » and can walk and move well within a few hours of birth. They normally stay close to their dam at least for the first three days of life and then spend most of the time within easy reach of her until they are several weeks old. Ewes normally feed their own lambs exclusively, and alien lambs are butted away. This behaviour pattern demands that the ewe and lamb recognise each other and it is clear from field observations that recognition of the lamb by the ewe develops very quickly. It seems too that the lamb learns to recognise its mother quickly, but that this recognition is more adaptable and slower to develop than that of the ewe for the lamb.

There are normally two behaviour patterns which indicate that the ewe and lamb have identified each other. One is the event of suckling, if a ewe will permit a 
lamb to suck it means that she has recognised the lamb as her own, or has failed to identify it as an alien. Secondly, when lambs are given a choice of ewes they will run to their own dam and stay very near, or when ewes are given a choice of lambs they will approach and stay near. This behaviour of the ewes may be delayed a little because, in the field, lambs normally run to their ewe more than ewes move to their lambs. But if $a$ ewe is searching for her lamb she will move very close to any lamb to investigate it.

So, how do ewes and lambs recognise each other? What role does each sense play in this identification? These questions can be answered in two ways. 1) The sensory receptors can be interfered with, so the animals can be deafened, made anosmic or temperarily blinded. 2) The sensory clues received can be altered. It is this second method which we have used in most of the experiments carried out with ewes and lambs, taking the two behaviour patterns described as criteria of recognition.

\section{The importance of visual clues.}

In 1973 the general impression was that olfaction was the most important sense used in ewe/lamb recognition. Ewes and lambs coming together always seemed to sniff various parts of each other's body and Smith (1965), and Smith, Van Toller and Boyes (1966) gave it priority amongst the senses in forming the ewe-lamb bond.

However, after watching sheep in the field, it seemed that recognition occurred when ewe and lambs were some distance apart, and too far apart for olfaction to function. Using sheep of different breeds and appearance, the behaviour of ewes was observed when meeting their own lambs, alien lambs of the same breed and appearance, and lambs of different breeds and different appearance. Similarly the behaviour of lambs meeting their own ewes, and ewes of varying appearance was recorded (Shillito and Alexander, 1975).

Ewes and lambs were separated for 30-60 min before the tests, and then a ewe was released from one end of the observation area and a lamb from the other. Each ewe was tested with her own lamb and with alien lambs. Their behaviour was recorded for $30 \mathrm{sec}$ and the degree of interest in each other was rated. As expected the ewes showed more interest in their own lambs, and in lambs of the same colour as their own. They showed little or no interest in a dissimilar lamb. The results for the lambs were similar and became more specific as they became older. So it seemed that the appearance of the ewes and lambs was clearly influencing the degree of interest of ewes and lambs in alien partners, and this suggested that mutual recognition was at least partly dependent on vision.

So what happens if the appearance of a ewe or her lamb is changed? Do they still recognise each other and allow sucking, or do they behave like aliens meeting and not get near to each other?

Working with Merino sheep which were all alike, Alexander (1977) coloured ewes and lambs black by brushing carbon black powder into the wool. He found that lambs 1-4 days old were not really affected by changes in the ewes, but older lambs slowed and hesitated in their approach to their own ewes. He concluded that in Merino lambs the importance of visual clues relative to auditory clues increased between the 2nd and 4th week of life. 
The response of the Merino ewes to change in colour of their own lambs was much more marked. Not only was there hesitation and slowing in the response towards the lamb, but also a definite avoidance and running away. This behaviour was investigated more fully using lambs coloured with white, yellow, green, brown, red and black powders (Alexander and Shillito, 1978).

The tests were carried out on 70 Merino ewes and their lambs of 4-11 days old. The ewes and lambs were separated for $2 \mathrm{~h}$ before testing began. Then each ewe and her lamb were released from opposite ends of a screened enclosure $8 \times 14 \mathrm{~m}$. The behaviour was recorded to note the speed at which the ewe and lamb approached each other, the incidence of hesitation or avoidance, and butting, and the time taken for the lamb to suck. After the first test, the ewe and lamb were separated and the lamb was coloured with one of the powders. They were run together again as before, and the behaviour recorded.

The results showed that in all groups with coloured lambs there was a greater tendency for ewes to move towards the lamb at slow speed, than in the control test immediatelly prior to colouring or in the uncoloured group (table 1). Although differences were small and not significant, the tendency was least marked with the white and yellow and most marked with the black.

TABLE 1

The effect of colouring their own lambs on the behaviour of Merino ewes

\begin{tabular}{|c|c|c|c|c|c|c|c|c|}
\hline & \multicolumn{6}{|c|}{ Number of ewes } & \multirow{2}{*}{\multicolumn{2}{|c|}{$\frac{\text { Lambs }}{\text { Time to suck }}$}} \\
\hline & \multicolumn{2}{|c|}{ Speed } & \multicolumn{2}{|c|}{ Hesitation } & \multicolumn{2}{|c|}{ Butting } & & \\
\hline & fast & slow & no & yes & no & yes & $<15 \mathrm{sec}$ & $>15 \mathrm{sec}$ \\
\hline $\begin{array}{l}\text { Control } \ldots \ldots \ldots \ldots \\
\text { White } \ldots \ldots \ldots \ldots \\
\text { Yellow } \ldots \ldots \ldots \ldots \\
\text { Green..... } \\
\text { Brown } \ldots \ldots \ldots \ldots \ldots \\
\text { Red } \ldots \ldots \ldots \ldots \ldots \\
\text { Black } . . . \ldots \ldots \ldots\end{array}$ & $\begin{array}{l}7 \\
6 \\
6 \\
5 \\
5 \\
5 \\
4\end{array}$ & $\begin{array}{l}3 \\
4 \\
4 \\
5 \\
5 \\
5 \\
6\end{array}$ & $\begin{array}{r}10 \\
10 \\
2 \\
1\end{array}$ & $\begin{array}{r}8 \\
10 \\
9 \\
10 \\
10\end{array}$ & $\begin{array}{r}10 \\
10 \\
10 \\
9 \\
7 \\
8 \\
3\end{array}$ & $\begin{array}{l}1 \\
3 \\
2 \\
7\end{array}$ & $\begin{array}{r}10 \\
10 \\
9 \\
3 \\
4 \\
1 \\
1\end{array}$ & $\begin{array}{l}1 \\
7 \\
6 \\
9 \\
9\end{array}$ \\
\hline
\end{tabular}

Most ewes confronted with coloured lambs showed some degree of hesitation or avoidance in the test, in contrast to the ewes meeting normal or whitened lambs. Avoidance behaviour was more marked and prolonged with the red, black and brown colours; it frequently continued for several minutes with the ewe running round the enclosure with the lamb in pursuit. Eventually the lamb was able to approach the ewe and all were accepted by their ewes regardless of colour within about $5 \mathrm{~min}$. Some ewes butted the lambs as they attempted to reach the udder. This was particularly marked with the black lambs $(P=0.002)$.

The time taken for the lambs to suck, reflects the length of avoidance behaviour. It was shorfest with the normal, yellow and white lambs which sucked within $15 \mathrm{sec}$. The red and black lambs took the longest time to suck $(P<0.001$ in analysis of 
variance of values under $3 \mathrm{~min}$ ). With green and brown lambs the duration was significantly longer than with normal lambs $(P<0.01)$ but significantly shorter than with black lambs $(P<0.05)$.

When the seven colour groups were ranked according to the severity of the effect on each of the parameters examined, the overall ranking was black, red, brown, green, yellow, with untreated and white equal last having no discernable effects. So it seemed that the ewes were considerably disturbed by their own lambs being dark coloured, and slightly affected by the green and yellow. The very marked avoidance was a flight response to changed visual appearance of the lamb which bleated normally and moved normally, so obviously sight has an important role in ewe/lamb recognition. What effect would only partial colouring have on the response of the ewe to her own lamb?

The importance of visual clues from various body regions of the lamb in maternal recognition by the ewe was investigated in a similar way to that described previously, except that various parts of the lamb were coloured with carbon black (fig. 1) (Alexander and Shillito, 1977a, b).

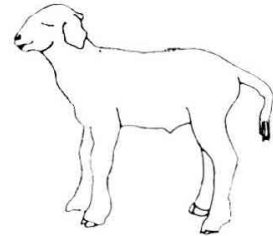

CONTROL

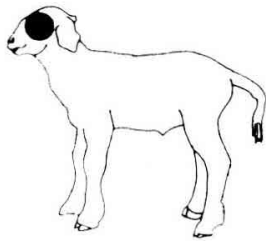

BLACK EYES

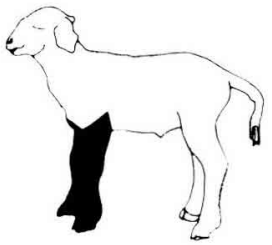

BLACK FORELEGS

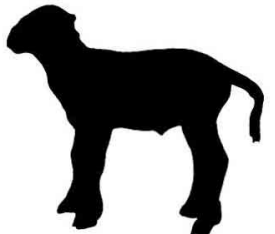

ALL BLACK

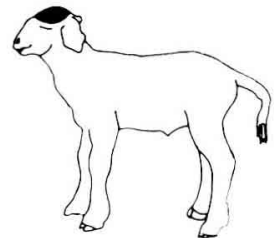

BLACK CROWN

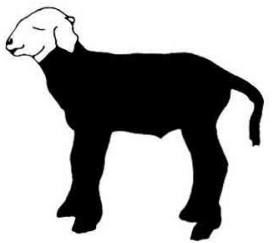

BLACK BODY

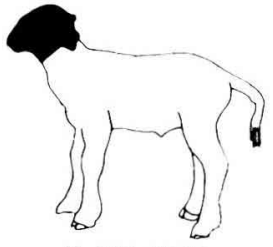

BLACK HEAD

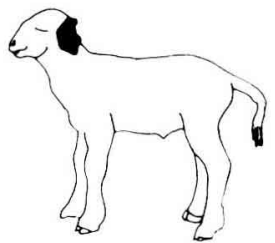

BLACK EARS

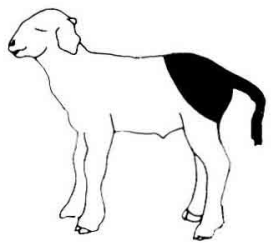

BLACK RUMP

FIG. 1. - Lambs' body regions that were blackened.

Colouring the front legs, or the ears or the rump together with the tail of the lamb, made little effect on the recognition response of the ewe. However, 70 p. 100 of the ewes with lambs with black rumps and tails circled when the lamb was near the udder. This compares with 10 p. 100 in control trials. So the ewe appeared to react to a visual change in the tail region when the lamb was very near. 
The percentage of ewes that approached their lambs slowly was slightly increased when the lambs were coloured completely black (table 2), or given a black head or body and legs, but the increase was statistically significant only when the head alone was blackened $(P<0.05)$. These were the lambs that were butfed by the ewes.

TABLE 2

The effect of colouring various ports of the lamb's body, on the behoviour of Merino ewes

\begin{tabular}{|c|c|c|c|c|c|c|c|c|}
\hline & \multicolumn{6}{|c|}{ Number of ewes } & \multirow{2}{*}{\multicolumn{2}{|c|}{$\frac{\text { Lambs }}{\text { Time to suck }}$}} \\
\hline & \multicolumn{2}{|c|}{ Speed } & \multicolumn{2}{|c|}{ Hesitation } & \multicolumn{2}{|c|}{ Butting } & & \\
\hline & fast & slow & no & yes & no & yes & $<15 \mathrm{sec}$ & $>15 \mathrm{sec}$ \\
\hline $\begin{array}{l}\text { Control } \ldots \ldots \ldots \\
\text { Front legs } \ldots \ldots \ldots \\
\text { Tail } \ldots \ldots \ldots \ldots \\
\text { Ears } \ldots \ldots \ldots \ldots \\
\text { Eyes } \ldots \ldots \ldots \ldots \\
\text { Crown } \ldots \ldots \ldots \ldots \\
\text { Body } \ldots \ldots \\
\text { Head } \ldots \ldots \\
\text { All black } \ldots \ldots \ldots\end{array}$ & $\begin{array}{l}7 \\
8 \\
6 \\
8 \\
7 \\
7 \\
5 \\
2 \\
4\end{array}$ & $\begin{array}{l}3 \\
2 \\
4 \\
2 \\
3 \\
3 \\
5 \\
8 \\
6\end{array}$ & $\begin{array}{r}10 \\
10 \\
9 \\
8 \\
3 \\
5 \\
4\end{array}$ & $\begin{array}{r}1 \\
2 \\
7 \\
5 \\
6 \\
10 \\
10\end{array}$ & $\begin{array}{r}10 \\
10 \\
10 \\
10 \\
10 \\
9 \\
10 \\
6 \\
3\end{array}$ & $\begin{array}{l}1 \\
4 \\
7\end{array}$ & $\begin{array}{r}10 \\
10 \\
10 \\
9 \\
9 \\
9 \\
9 \\
4 \\
2\end{array}$ & $\begin{array}{l}1 \\
1 \\
1 \\
1 \\
6 \\
8\end{array}$ \\
\hline
\end{tabular}

The incidence of hesitation and avoidance was greatest (100 p. 100) in ewes with lamb which had black heads or which were completely black. Some of the ewes hesitated when their lambs had black eyes, black crowns or black bodies. In general the prolonged avoidance seen with the completely red, black and brown lambs did not occur, but the time taken for the lambs to suck was greater than 15 sec in the lambs with black heads or which were completely black.

These results indicated that the visual clues used by a Merino ewe to identify her own lamb came largely from the head region. Lambs with black heads elicited more response than lambs with white heads and black bodies. The lambs with blackened crowns and eyes also elicited uncertain behaviour from the ewes.

All these results were obtained from white Merino ewes living with other white sheep. To investigate whether ewes from other breeds with spotted or black and white lambs would behave in the same way, a small test was carried out on 10 Jacob ewes. These sheep are black and white and often have lambs with black eyes and crowns. The head of the lambs were blackened to cover up the white areas, and the ewe and lambs were run together as before.

The results showed that $9 / 10$ of the ewes hesitated or dodged when their lambs approached, but only one ewe butted her lamb. The mean time to suck was delayed to $21.4 \mathrm{sec}$ from a control mean of $11.4 \mathrm{sec}$ but this was because only 5 of the ewes took much longer than the control time. So even with sheep that are familiar with variegated lambs, there was some hesitation and an indication that the ewes were looking at the heads of the lambs as they ran towards them. Possibly the tremendous startle response seen in Merino sheep was the result of unfamiliarity with coloured sheep. 
The conclusion from these experiments was clearly that ewes use vision in recognition of their lambs, and that the ewes seem to look at the lamb's heads as part of this recognition. The subject of colour vision in ewes does not come within the scope of this paper, but further work has been published (Alexander and Shillito, 1978 ; Alexander and Stevens, 1979).

\section{Relative importance of vision, hearing and smell.}

The relative importance of visual clues to olfactory and auditory clues in lamb recongition by ewes, was investigated with Merino ewes in the following way (Alexander and Shillito, 1977b). Ewes were released singly into a corridor between two wire mesh fences and were presented with a choice of three lambs in separate wire cages adjacent to one side of the corridor. One of the cages contained the ewes' own lamb. The lambs were treated in various ways to remove or alter clues that the ewe might use to identify her lamb. Auditory clues (fig. 2, A) were altered or abolished by injecting the lamb's vocal cords with local anaesthetic $(2 \mathrm{ml} 2 \mathrm{p}$. 100 lignocaine hydrochloride). At the same time the ewe's ears were blocked with putty. One component of the visual clues (V) was abolished by screening the cages with hessian leaving an unscreened airway at the bottom of the cage for the passage of odour. The second component of vision was movement $(M)$ from the lamb and this was abolished by anaesthetizing the lambs with pentobarbitone sodium $100 \mathrm{mg}$ IV. Anaesthetized lambs were also unable to vocalize. Olfaction ( 0 ) was altered by having the cages holding the lambs adjacent to the wire corridor or 0.25-0.5 m away.

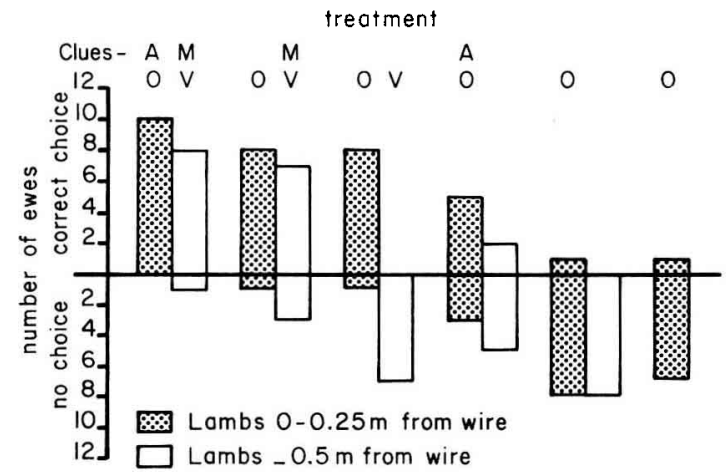

FIG. 2. - The number of ewes making a correct choice or no choice in experiments to test the relative impor. tance of sensory clues in lamb recognition. $A=$ auditory clues. $M=$ movement. $V=$ visual clues. $\mathrm{O}=$ olfactory clues. Various clues were removed by treating the lambs in 6 treatment groups.

The ewes and lambs were separated for about 2-4 $\mathrm{h}$ before the tests began. There were 12 ewes in each of the six treaiment groups. Recognition of a lamb by a ewe was signified by the orientation of the ewe to the lamb, whether it stood near the cage for at least $20 \mathrm{sec}$ and whether the ewe bleated or rumbled. $120 \mathrm{sec}$ were allowed for each ewe to make a choice. A correct choice was identification of her own lamb, an incorrect choice was when the ewe seemed to stand by an alien lamb, and « no choice» was when the ewe made no definife orientation towards any cage. 
When the lambs were near to the wire corridor the performance of the ewes that could see and were free to smell their lambs, but not to hear them, was only slightly inferior to that of control ewes (fig. $28 / 12$ as opposed to $10 / 12$ controls). Fewest correct scores and most failures to choose were recorded with ewes that were free to smell, but could neither see nor hear their lambs. The difference between the two sets of treatments was highly significant $(P<0.001)$. Ewes that could not see their lambs, but were free to smell and hear fell between these two extremes. The number of ewes that chose correctly $(5 / 12)$ was significantly lower $(P<0.02)$. So these results indicated that smell alone appeared to be ineffective in attracting the ewe. Auditory clues seemed to assist the ewe especially when visual clues were absent, but the effect of removing visual clues tended to be greater than the effect of removing auditory clues.

When the lambs were $0.25-0.5 \mathrm{~m}$ away from the ewes, there was an interesting result with the unscreened, anaesthetized lambs. The ewes seemed unable to make a definite choice of lamb, which showed that smell was ineffective at that distance and that the visual clues from an immobile lamb were weak. In contrast, the ewes were able to identify their lambs when active but muted and $0.25 \mathrm{~m}$ away. The difference in results between these two treatments was statistically significant $(P<0.01)$. When lambs were screened and screened and anaesthetized and away from the corridor, the ewes were unable to make definite choices of lambs.

The results of these last experiments with Merino ewes seemed to emphasise the importance of visual clues, and particularly the movement of the lamb in attracting the attention of the ewe. Scent seemed only to be important when the lamb and ewe were very near, and the function of auditory clues seemed to be very small.

\section{The importance of olfaction.}

More recently Alexander has investigated the use of olfaction in recognition o lambs by Merino ewes (Alexander, 1978). Using a similar experimental set up with a corridor and ancesthetized lambs in cages, he investigated whether the ewes could distinguish their own lamb by smelling the head of the lamb or the tail region. The results showed that the ewes could use both regions for olfactory identification, providing the lamb was near to the ewe. The ewes seemed to prefer to spend longer investigating the tail region.

Several unsuccessful attempts have been made to mask the odour of lambs by covering up their own smell by another. Alexander (unpublished) has used triethylamine, oil of wintergreen, vanilla and mercaptoethanol and civit and castoreum from civit cat and beaver respectively.

Alexander and Stevens (in preparation) have had some interesting results using lambs washed in detergent. Using the same method as before with anaesthetized lambs, comparison was made between unwashed lambs, lambs sprayed with detergent (0.05 p. 100 solution of a neutral non-ionic detergent Nonidet grade 91/6, Shell Chemical (Australia) Pty Ltd.), lambs scrubbed with detergent and rinsed and washed lambs tainted with another lambs faeces. Some of the washed lambs were placed with their heads near to the ewe, and some were placed with their tails nearest to the ewe. 
Ten of the twelve ewes fested with unwashed anaesthetized lambs could identify their lamb positively, and 11/12 chose lambs sprayed with detergent (table 3). But washing lambs reduced the success rate of the ewes $(P<0.01)$ and 3 ewes chose aliens, 3 chose their own and 6 made « no choice ». Only one ewe chose her lamb when the head was nearest the ewe, and interest in the head was less than in the fail end. When faeces were smeared on washed lambs, only 3 ewes correctly chose the faeces from their own lamb, none chose their own lamb and one chose an alien. Some tests with conscious, washed lambs showed that ewes could identify their own unanaesthetized lambs. So these results indicated that scrubbing lambs in detergent solution effectively removed the specific odour recognised by the ewe, and that ewes were not confused by any residual odour of the detergent. It seemed that the attractive tail odour was not simply a specific faecal odour. Obviously conscious, active, scrubbed lambs provide other clues by wich the ewes can identify them.

TABLE 3

Number of ewes choosing own or alien lambs or making no choice in experiments with washed lambs

\begin{tabular}{|c|c|c|c|c|c|}
\hline & \multirow{2}{*}{ Treatment } & & \multicolumn{3}{|c|}{ Ewes } \\
\hline & & & own & alien & n.c. \\
\hline \multirow{2}{*}{ Anaesthetized } & Not washed & $\begin{array}{l}\text { normal } \\
\text { sprayed }\end{array}$ & $\begin{array}{l}10 \\
11\end{array}$ & $\begin{array}{l}0 \\
1\end{array}$ & $\begin{array}{l}2 \\
0\end{array}$ \\
\hline & Washed & $\begin{array}{l}\text { head } \\
\text { tail } \\
\text { faeces }\end{array}$ & $\begin{array}{c}1 \\
3 \\
0 \\
3 \mathrm{~F}\end{array}$ & $\begin{array}{l}0 \\
3 \\
1\end{array}$ & $\begin{array}{r}11 \\
6 \\
8\end{array}$ \\
\hline Conscious & Washed & $\begin{array}{r}5 \text { days } \\
28 \text { days }\end{array}$ & $\begin{array}{l}11 \\
12\end{array}$ & $\begin{array}{l}0 \\
0\end{array}$ & $\begin{array}{l}1 \\
0\end{array}$ \\
\hline
\end{tabular}

However, there seemed to be some prolonged effects of washing on maternal care because Alexander and Stevens found that two days following the tests, 16 out of 36 lambs which were scrubbed, were not being fed by their ewes whereas all 24 of the unwashed but anaesthetized lambs were being cared for. This behaviour was seen in lambs 5 days old, but when lambs 4 weeks old were tested only $1 / 12$ ewes butted her washed lamb away.

These results are important because they show that Merino ewes can identify their lambs by non-olfactory clues and then reject them after olfactory examination. Further it seems that correct olfactory clues are necessay before the ewe will permit her lamb to suck.

In recent experiments with cross fostering lambs between Dalesbred and Clun Forest breeds of sheep (Shillito Walser unpublished), it was clear that amniotic fluid and also blood and fluid from the placenta could effectively mask the odour of the alien lamb, but immediate butting away of the lambs by the foster mother suggested 
that the visual appearance of the lamb was also important even in as short a period as two hours after parturition. Lambs soaked in their foster mother's amniotic fluid were first butted and then sniffed by the foster ewe.

\section{The importance of vocalization and hearing.}

In all these experiments described, the role of vocalisation and hearing in mutual recognition between ewes and lambs has seemed to be minor and mainly that of attracting the ewes attention to the lamb. As far as the ewe is concerned, the voice of the lamb does not seem to be very important in recognition. Working with ewes of Clun Forest, Finnish, Jacob, Dalesbred and Soay breeds of sheep (Shillito Walser, 1978), it was found that when ewes were given a choice of three litters of lambs hidden behind canvas, only 48 p. 100 of then could identify their lambs correctly. When the lambs were visible, the ewes made a very rapid identification, 87 p. 100 of them orienting from 16 metres away.

The role of hearing in lambs finding their dams seems to be more important, particularly when the lambs are more than 21 days old (Shillito, 1975). When ewes of the same breed were hidden behind canvas, 60 p. 100 of lambs could find their mothers. There was a significant difference in performance of lambs under 7 days and the accuracy of the lambs improved up to 21 days when 78 p. 100 of the lambs could locate their ewe by voice. So this suggests that recognition of the ewes' voice is learnt by the lambs. There seemed to be a difference in the ability of different breeds. The Jacob lambs were significantly poorer $(P<0.05)$ in finding their ewes by voice, and the Dalesbred lambs were the most accurate (Shillito Walser, 1980). Dalesbred sheep come from the hills and its may be that the lambs need to find their ewes more often when they are out of sight, in contrast to the sheep living in flat areas. The Jacob lambs had ewes varying in appearance, because the ewes are marked differently in black and white. It may be that the lambs had learnt to use visual clues rather than auditory clues.

Different breeds of sheep behave in different ways, and the results we have presented apply mostly to Merino and some English breeds of sheep. However, they show that sheep seem to use visual clues in recognition between ewes and lambs at a distance. These may be more important to ewes than lambs, whereas lambs may learn to use vocal clues more than ewes. Vocalisation and movement elicit the attention of both ewes and lambs and as such they have an important role. Olfaction seems to provide the most specific and finally determining clues for recognition between ewes and lambs. The presence of the correct scent seems to be essential for the ewe to permit suckling. So olfaction seems to be the most important sense in mutual recognition, but without vision and hearing the ewe and lamb might never get near enough to each other for olfaction to function in this recognition.

Colloque « La relation parentale » Nouzilly, France, juin 1979.

Résumé. Les auteurs décrivent des études dont le but est d'examiner la valeur relative de la vue, de l'audition et de l'olfaction dans la reconnaissance mutuelle entre les brebis et les agneaux. Plutôt que de perturber la perception sensorielle des animaux, la méthode 
employée est de changer des indices qui pourraient intervenir dans la reconnaissance. Le changement de l'aspect des agneaux, par coloration, provoque un comportement d'évitement de la part des mères. Dans les cas d'agneaux colorés partiellement, ceux dont la tête est colorée provoquent la plus forte réaction de la part des brebis. D'autres expériences comparent le rôle de la vue et de l'audition en observant la reconnaissance lorsque les brebis ou les agneaux sont cachés derrière des écrans ou sont rendus muets. A partir des résultats, il semble que, si l'olfaction joue un rôle important dans la reconnaissance lorsque la brebis est proche de l'agneau, les signaux visuels ont une importance capitale en discrimination maternelle et les signaux auditifs en ont également pour les agneaux lorsqu'ils grandissent.

\section{References}

ALEXANDER G., 1977. Role of auditory and visual clues in mutual recognition between ewes and lambs in Merino Sheep. Appl. Anim. Ethol., 3, 65-81.

ALEXANDER G., 1978. Odour and the recognition of lambs by Merino ewes. Appl. Anim. Ethol., 4, 153-158.

ALEXANDER G., SHILLITO E., 1977a. Importance of visual clues from various body regions in maternal recognition of the young in Merino sheep (Ovis aries). Appl. Anim. Ethol., 3, 137-143.

ALEXANDER G., SHILLITO E., 1977b. The importance of odour, appearance and voice in maternal recognition of the young in Merino sheep (Ovis aries). Appl. Anim. Ethol., 3, 127-135.

ALEXANDER G., SHILLITO E., 1978. Maternal responses in Merino ewes to artificially coloured lambs. Appl. Anim, Ethol., 4, 141-152.

ALEXANDER G., STEVENS D., 1979. Discrimination of colours and grey shades by Merino ewes : Tests using coloured lambs. Appl. Anim. Ethol., 5, 215-232.

ALEXANDER G., STEVENS D. Recognition of washed lambs by Merino ewes. Appl. Anim. Ethol. (submitted for publication).

SHILLITO E., 1975. A comparison of the role of vision and hearing in lambs finding their own dams. Appl. Anim. Ethol., 1, 369-377.

SHILLITO E., ALEXANDER G., 1975. Mutual recognition amongst ewes and lambs of four breeds of sheep (Ovis aries). Appl. Anim. Ethol., 1, 151-165.

SHILLITO WALSER E., 1978. A comparison of the role of vision and hearing in ewes finding their own lambs. Appl. Anim. Ethol., 4, 71-79.

SHILLITO WALSER E., 1980. Maternal recognition and breed identity in lambs living in a mixed flock of Jacob, Clun Forest and Dalesbred sheep. Appl. Anim. Ethol., 6, 221-231.

SMITH F. V., 1965. Instinct and learning in the attachment of lamb and ewe. Anim. Behav., 13, 84-86.

SMITH F. V., VAN TOLLER C., BOYES, T., 1966. The "critical period " in the attachment of lambs and ewes. Anim. Behav., 14, 120-125. 